\title{
The Effect Of Family Firm On The Credit Rating: Evidence From Republic Of Korea
}

Soo-Joon Chae, Ph.D., Kangwon National University, South Korea

Kwangwuk Oh, Ph.D., Korea University, South Korea

\begin{abstract}
This studyexamined whether there were differences in the credit ratings offamily firms, one type of business ownership and corporate governance in Korea. Credit rating agencies which evaluate a company's ability to pay back the debt play a key role in evaluating corporate values in the capital market. A variety of standards are applied to evaluate corporate credit ratings. The corporate governance structure is also under consideration. Credit rating agencies may give excellent credit ratings to family firms if they judge that family companies have efficient governance structures resulting in lower agency costs as companies which try to match minority shareholders' interests. On the other hand, they may give lower credit ratings to family firms if they judge that family firms have a negative impact on firm performance. In this context, this study planned to investigate how credit rating agencies constituting the mainstay in the evaluation of corporate values with analysts judged the roles of family firms which had been controversial in previous studies in the capital market, and present directresults.
\end{abstract}

Keywords: Family Firm; Credit Rating; Chaebol

\section{INTRODUCTION}

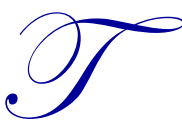

his study analyzed whether there were differences in the credit ratings of family firms, one type of business ownership and corporate governance in Korea. The previous studies on family firms had analyzed the effects of family firms on the quality of earnings, management performance, and others all the while. They did not show consistent results. When family firms are examined in terms of traditional agency costs, it is still a controversial issue that the majority shareholder infringes on minority shareholders' wealth, or match with minority shareholders' interests to achieve the goal, the maximization of minority shareholders' wealth.

Credit rating agencies which evaluate a company's ability to pay back the debt play a key role in evaluating corporate values in the capital market. A variety of standards are applied to evaluate corporate credit ratings. The corporate governance structure is also under consideration. Credit rating agencies may give excellent credit ratings to familyrun firms if they judge that family firms have efficient governance structures resulting in lower agency costs as firms which try to match minority shareholders' interests.

In this study, family firms in Korea are defined based on the two standards as follows: whether the family member of the real owner of the company, namely the majority shareholder, participates in the corporate management; whether the majority shareholder's family member holds $5 \%$ or more ownership (shareholding) in the relevant company. In other words, the company was classified as a family company when the majority shareholder's family member participated in the corporate management and holds shareholdings representing at least $5 \%$ of shares and voting rights in the company. It can be seen that the interest alignment hypothesis is supported when credit rating agencies give better credit ratings to the company that the majority shareholder's family member has directly participated in the management as a member of the Board of Directors. They may also have judged that a family company had the positive management environment and business competitiveness when they gave a better credit rating to a family company in evaluating corporate management environment and business competitiveness. In this context, this study is meaningful in that it investigated how credit rating agencies constituting the mainstay in the evaluation of corporate values with analysts judged the roles of family companies which had been controversial in previous studies in the capital market, and present direct results. 
This study consists of the following. summarizes previous studies and sets forth the hypothesis of this study. explains the process of selecting samples used for testing of the hypothesis and study model. explains the results of empirical analysis, and summarizes the conclusions and contributions of this study.

The remainder of the paper is organized as follows. Chapter II presents the findings from the relevantliterature and develops the testable hypothesis based on relevant literature. Chapter III describes the sample selection and research design. Chapter IV reports the empirical results. Chapter V offers conclusions and implications.

\section{LITERATURE REVIEW AND HYPOTHESES}

\section{Literature Review}

There had been no universally agreed definition of the family firm so far. The family firm had been defined in various ways in previous studies. Faccio et al. (2001) studied majority shareholders' arbitrary management. They classify the firm that the founder's family owns $20 \%$ or more of shares as a family-controlled firm, and present that there are many companies whose real owners are the founders' families in East Asian countries such as Korea. Handler (1989) takes precaution against the studies using only one of those standards, maintaining that 'there are fundamental differences between the studies that family companies are defined based on the ruling family's participation into the corporate management and those that family companies are classified based on the ruling family's ownership. Reflecting this opinion, many recent studies on family companies had used the two standards, management participation and ownership, at the same time to define the family firm. Westhead and Cowling (1998) in Great Britain define the family firm, manifoldly considering whether family members participate in the corporate management as CEOs or members of the Board of Directors. Anderson and Reeb (2003) classify companies as family and non-family companies based on the percentage of shares owned by the founder's family, and the founder's family members as the members of the Board of Directors.

To sum up the results of the previous studies, the family firm may be defined in three ways: the participation of the real owner of the firm, namely the ruling family, into the corporate management; the ruling family's ownership (shareholding) at more than a certain level in the relevant firm; and the complex use of the two standards. This study intended to investigate whether credit ratings had differently been given to companies owned and controlled families. This study defined the family firm, using both of the two standards, the ruling family's direct participation into the corporate management and the percentage of its shares.

It is mandatory to attach the credit rating evaluated by credit rating agencies when a company issues its corporate bonds to raise long-term (one year or more) funds directly in the financial market. Therefore, companies which issue their corporate bonds may make efforts in various ways to get better credit ratings.

There are three credit rating agencies such as Korea Ratings, Nice Investors Service Ratings, and Korea Investors Service Ratings in Korea. They publicly announce their credit rating methodologies for each business sector on their websites every year. As a result of examining the evaluation methodologies of credit rating agencies, the main contents of their evaluations are summarized as table 1.

Among many items, management policies, corporate governance structure, policy effectiveness, staff levels, and others are considered to analyze the management environment of the company. The company with a good corporate governance structure makes an effort to reduce the level of information asymmetry between managers and investors. As it creates the transparent financial environment, the good governance structure reduces the information asymmetry between managers and investors, and contributes to an increase in corporate performance and values. Credit rating agencies may give a higher credit rating to the family company where the owner's family member participated in the management as a member of the Board of Directors when they judgethat the relevant company has a good corporate governance structure. 
Table 1. Main factor of credit rating evaluation

\begin{tabular}{|c|c|}
\hline Category & Detailed item \\
\hline Industrial Environment & $\begin{array}{l}\text { General characteristics of the industry, the internal structure of the industry, and } \\
\text { competitive factors }\end{array}$ \\
\hline \multirow{2}{*}{ Management Environment } & $\begin{array}{l}\text { Management policies, corporate governance structure, policy effectiveness, and staff } \\
\text { levels }\end{array}$ \\
\hline & $\begin{array}{l}\text { The current state of affiliated companies and interdependence among affiliated } \\
\text { companies }\end{array}$ \\
\hline Business Competitiveness & Position, competitiveness, and share in the market \\
\hline Profitability and Financial Structure & Growth, profitability, financial policy and structure \\
\hline
\end{tabular}

\section{Hypothesis Development}

A credit rating represents the system that the financial and non-financial data, and the relationship with affiliated companies of the company which issued bonds, the business sector of the company, the characteristics of the industry, the business environment, and others are analyzed to evaluate a company's ability to pay back the principal comprehensively, and officially announce its rating. The independent and objective credit rating given after the credit worthiness of a debtor (a company) is evaluated adjusts the problem of information asymmetry in the capital market to improve the efficiency of the capital market (Standard and Poor's 2001). Credit rating agencies consider the governance structure to assign credit ratings because there is a high possibility that the financial condition of the company is damaged and creditors face losses when the company has the poor governance structure (FitchRatings 2004).

Standard \& Poor's Corporate Governance Scores (2002) also reports that transparency involves the timely disclosure of adequate information concerning a firm's operating and financial performance and its corporate governance practices. For a well-governed firm, standards of timely disclosure and transparency are high. This enables shareholders, creditors and directors to effectively monitor the actions of management and the operating and financial performance of the firm.

The previous studies also show that the excellent credit rating is given because the corporate governance structure reduces the level of information asymmetry. Ashbaugh et al. (2006) studied the relationships between the characteristics of various corporate governance structures and credit ratings systematically. As a result of their investigation, it is shown that the larger the number of outside directors is, the more the chairperson of the Board of Director is separated from the CEO, and the more financial professionals are within the Board of Directors, the better credit ratings were given because the level of information asymmetry is reduced. Bhojraj and Sengupta(2003) state that the stronger the governance structure, the higher credit rating is given and the lower capital cost is shared, mentioning the effects of the governance structure on agency problems and the level of information asymmetry.

Verrecchia(1983) reports that companies tended to reduce the level of information asymmetry to lower the cost required to raise external funds. Bushman and Smith (2001) mention that the public announcement to reduce the level of information asymmetry may play a role in improving a company's ability to invest in profitable investment alternatives. Sengupta (1998) maintains that the corporate governance structure reduces the level of information asymmetry to influence bond ratings and the rate of return. The Board of Directors plays a role in lowering the agency cost of the management and stakeholders and is recognized as one of the important factors which influence the reliability of the financial reporting process in the light of creditors because it functions to monitor and check the management (Dichev and Skinner 2002). Klein (2002) states that the characteristics of the Board of Directors which monitors the financial reporting process influence the validity of accounting information. Smith and Warner (1979) maintain that the bond price depends on the characteristics of the Board of Directors when the capital cost related to the effectiveness of the creditor's debt contract is measured because the Board of Directors functions to supervise the financial reporting process. It is seen that creditors are highly interested in the corporate governance structure which influences the reliability of financial reporting because they depend on the debt contract based on accounting figures. Finally, it can be assumed that there is a possibility that credit rating agencies may give better credit ratings to 
companies which have the effective corporate governance structure, reflecting the creditors' expectation like this. Therefore, there is a possibility that better credit ratings may be given to the family companies which are judged to have the excellent governance structure. However, there has been no study on the effects of Korean family companies on credit ratings so far. The results of the previous studies on the effects of family companies on the capital market are also mixed.

Jensen and Meckling (1976) report that the constant problem about the agency related to managers' pursuit of private interests, and the level of information asymmetry may infringe the interests of shareholders or creditors. Lafond and Roychowdhury (2008) present an empirical result that conservatism is strengthened because the agency problem is intensified and the demand for conservatism consequentially increases as the separation of ownership measured by the percentage of shares owned by the manager the and control becomes severe. They also show a result that the conservatism of accounting information increases when the CEO is not the founder. Wang (2006) presents an empirical result that the quality of accounting earnings is high in case of the company owned by the founder's family. To sum up the results of previous studies, it is not easy to judge that the role of the majority shareholder as the corporate governance structure has a good or bad effect on credit ratings. Therefore, it is a question whether credit rating agencies evaluate family companies to have better governance structures than those of non-family companies, and give better credit ratings to them in evaluating the governance and ownership structure. In this context, the hypothesis of this study was set up in the form of a null hypothesis as follows:

Hypothesis: There is no relationship between family firm and creditrating.

\section{SELECTION OF SAMPLES AND STUDY METHODOLOGY SELECTION OF SAMPLES}

This study selected enterprises listed in the Korean Stock Exchange (KSE) stock market between 2000 and 2010 that satisfy following conditions:

(1) Firms not in financial industries

(2) Firms with December 31 fiscal year-end

We exclude financial firms in our sample because the format and nature of accounts on the financial statements in financial firms differ from those of other firms, making it challenging to perform an industry analysis. Lastly, we select firms with a December 31 fiscal year-end to facilitate comparison. Aslo Winsorization was performed on top 1\% and bottom 10 of variables used in the empirical analysis to control the effects of outliers. We collect data through KISVALUE database provided by NICE Credit Evaluation, Inc. After eliminating companies that do not have adequate data, the final sample consisted of 2,555 firm-year observations.

\section{Measurement of Family Firm}

It is first necessary to define the family-run company to investigate the conservatism of accounting information of family-run companies. Even though there are many different definitions of family companies in previous studies, this study used the definition of family companies, which might influence the computation of accounting information more directly in light of the conservatism of accounting information. Faccio et al.(2001) states that the family member of the real major shareholder exercises his or her influence when he or she occupies the key post such as the CEO or the chairperson of the Board of Directors. In other words, the family that owns a company can influence the conservatism of accounting information more directly when it directly participates in the corporate management. This study defines the company where the major shareholder's family member is a director (registered executive) or the CEO as a family company. However, the companies where held less than 5\% shares were not regarded as family-run companies because the companies were judged to have difficulty in exercising substantial control, referring to a previous study maintaining that management participation and the percentage of shares should complexly be considered (Handler 1989; Westhead and Cowling 1998). In other words, family companies were defined as companies which met two standards, the participation in the corporate management and the possession of $5 \%$ shares or more, at the same time in this study. 


\section{Research Model}

$$
i t+1=\beta_{0}+\beta_{1 i t}+\beta_{2} i t+\beta_{3} V_{i t}+\beta_{4 i t}+\beta_{5 i t}+\beta_{6} V_{i t}+\beta 7 i t+\beta 8 i t+\epsilon i t+
$$

This study used the data of the lowest bond credit ratings among credit ratings evaluated by three credit rating agencies (Korea Ratings, Nice Investors Service Ratings, and Korea Investors Service Ratings) as a surrogate variable in order to measure conservatively. Equidistant interval scores by stage ( 1 point at the lowest $\mathrm{C}$ grade, 2 points at the next lowest CC grade... 19 points at the next highest AA+ grade, and the 20 points at the highest AAA grade) were given for an analysis. A credit rating variable during the next term $(\mathrm{t}+1$ term) was used as a dependent variable to control the endogeneity problem, whereas an interest variable during the current term $(\mathrm{t}$ term) and other control variables were applied as independent variables.

\begin{tabular}{|c|c|c|}
\hline BONDit +1 & $=$ & Bond credit rating( 1 to 20 points) \\
\hline FAMit & $=$ & 1 if firms is a family firm, 0 otherwise. \\
\hline SIZEit & $=$ & The natural logarithm of the total asset \\
\hline LEVit & $=$ & Debt ratio (total debt/total asset) \\
\hline ROAit & $=$ & The return on total assets (net profit/ total asset) \\
\hline MBit & $=$ & The market-book ratio of capital (capital market value/book value) \\
\hline INTCOVit & $=$ & Interest coverage ratio (net earnings before taxes/interest cost) \\
\hline BETAit & $=$ & $\begin{array}{l}\text { Beta estimation, the number of months for five years before the relevant year as a variable } \\
\text { corresponding to the systematic risk. It is estimated through a market model, using return data. } \\
\text { KOSPI returns are used as market returns. }\end{array}$ \\
\hline ALTMANZit & $=$ & Altman Z-score $(=1.2 * \mathrm{WC}+1.4 * \mathrm{RE}+3.3 * \mathrm{EBIT}+0.6 * \mathrm{MV}+0.999 * \mathrm{SALES})$ \\
\hline$W C$ & $=$ & working capital/total assets \\
\hline$R E$ & $=$ & earned surplus /total assets \\
\hline$E B I T$ & $=$ & SALES net earnings before taxes /total assets \\
\hline$M V$ & $=$ & SALES capital market value/total debts \\
\hline SALES & $=$ & SALES sales/ total assets \\
\hline $\mathrm{i}, \mathrm{t}$ & $=$ & SALES firm and = year \\
\hline
\end{tabular}

In other words, the bond credit rating, a dependent variable in this study, was measured with the use of bond ratings during the next term $(t+1$ term), because it reflected the financial condition shown in the financial statements of a company, the corporate governance structure, and others to be subject to an ex post facto evaluation. The family company variable (Family), an interest variable, was measured as 1 when the members of the ruling family are the $\mathrm{CEO}$ or directors of the company, and hold $5 \%$ shares or more. Otherwise, it was measured as a dummy variable, 0.

It is necessary to control the variables which decisively influence credit ratings to verify the effects of family companies on credit ratings. Accordingly, the company size (SIZE) measured with natural logarithm of the total asset, the debt ratio (LEV), the return on total assets(ROA), the market-book ratio (MB), the interest coverage ratio(INTCOV), the largest shareholder's share percentage (LARGE), Beta estimation(BETA), listing on the KOSDAQ (MARKET), and the Altman Z-score (ALTMANZ) were included in the model. The size of a company was controlled as the size of the corporate asset measured with natural logarithm of the total asset. The debt ratio (LEV) is expected to have a negative (-) effect on the credit rating of the company because the higher the debtratio is, the higher the possibility of the corporate default becomes. The return on total assets (ROA) is assumed to exercise a positive (+) effect on the credit rating of the company because the higher the return on total assets, the lower the corporate default risk becomes (Francis et al. 2005). The high market-book ratio of capital (MB) means a high growth opportunity, a high accounting conservatism, and a low risk. Accordingly, the market-book ratio (MB) is expected to have a positive $(+)$ effect on the credit rating of the company because the higher the ratio is, the lower the risk premium becomes (Gode and Mohanram 2003). The interest coverage ratio (INTCOV) is also expected to have a positive (+) effect on the credit rating of the company because the higher the interest coverage ratio, the higher the company's ability to pay interests becomes (Sengupta 1998). The Beta estimation(BETA) corresponding to the market risk is 
assumed to have a negative (-) effect on the credit rating of the company as a variable estimated through a market model with the use of the monthly return data for the five years before the relevant year (Bhojraj and Sengupta 2003). The Altman (1968)의 Z-score used to determine corporate insolvency was included to control the effects of the stability of the profit structure and other financial variables on credit ratings. It is expected to have a positive (+) effect on credit ratings. Lastly, year dummy variables were included in control variables to control the effect of the particular year on credit ratings.

\section{EMPIRICAL RESULTS}

\section{Descriptive Statistics and Correlation Analysis}

The descriptive statistics of 2,555 samples used in this study are presented in Table 2 . As the average of bond credit ratings used as a dependent variable is 12.39 , the average credit ratings of samples are between $\mathrm{BBB}$ and $\mathrm{BBB}+$. As the average (median) of family company variables (FAMILY), a dummy variable determining family companies is 0.700 (1.000), $70 \%$ of family companies are shown to participate in the corporate management in Korea.

Table 2. Descriptive Statistics $(n=2,555)$

\begin{tabular}{l|r|r|r|r|r}
\hline Variable & Mean & $\begin{array}{c}\text { Standard } \\
\text { deviation }\end{array}$ & Minimum & Median & Maximum \\
\hline BOND & 12.39 & 3.87 & 1.00 & 12.00 & 20.00 \\
\hline FAMILY & 0.70 & 0.46 & 0.00 & 1.00 & 1.00 \\
\hline SIZE & 20.26 & 1.60 & 17.32 & 20.00 & 24.41 \\
\hline LEV & 0.52 & 0.19 & 0.14 & 0.53 & 0.99 \\
\hline ROA & 0.02 & 0.07 & -0.33 & 0.03 & 0.19 \\
\hline MB & 0.99 & 0.98 & 0.00 & 0.68 & 5.75 \\
\hline INTCOV & 15.60 & 56.51 & -24.96 & 2.34 & 455.74 \\
\hline BETA & 0.94 & 0.46 & 0.00 & 0.93 & 2.13 \\
\hline ALTMANZ & 672.14 & 826.80 & 1.16 & 369.80 & 4525.20 \\
\hline
\end{tabular}

The variable definitions:

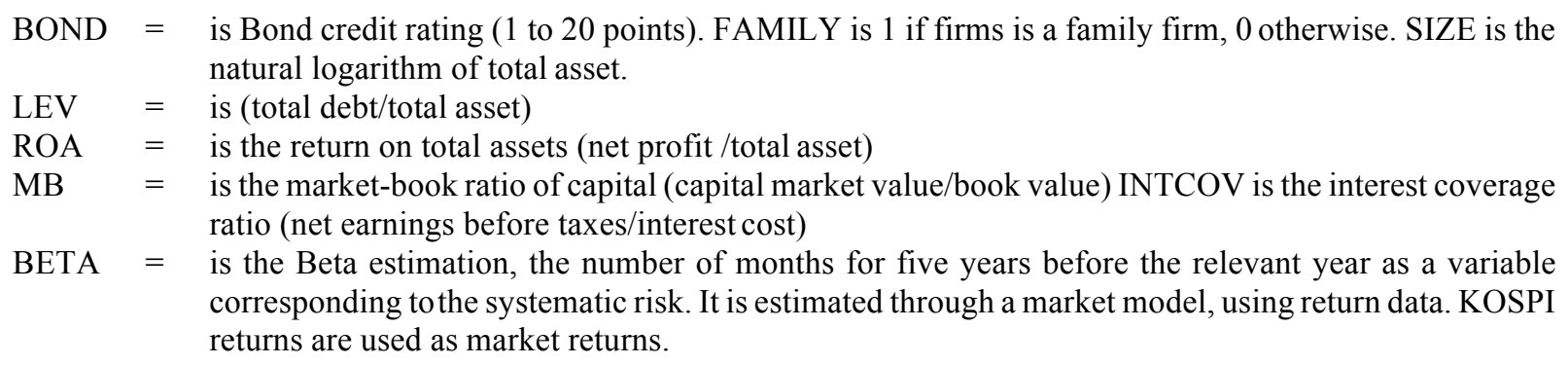

BETA $=$ is the Beta estimation, the number of months for five years before the relevant year as a variable corresponding to the systematic risk. It is estimated through a market model, using return data. KOSPI returns are used as market returns.

ALTMANZ is Altman Z-score $(=1.2 * \mathrm{WC}+1.4 * \mathrm{RE}+3.3 * \mathrm{EBIT}+0.6 * \mathrm{MV}+0.999 * \mathrm{SALES})$

$\begin{array}{ll}\mathrm{WC} & =\text { working capital/total assets } \\ \mathrm{RE} & =\text { earned surplus /total assets } \\ \mathrm{EBIT} & =\text { net earnings before taxes } / \text { total assets } \\ \mathrm{MV} & =\text { capital market value/total debts } \\ \text { SALES } & =\text { sales/ total assets }\end{array}$

Table 3 shows the correlation among variables used in this study. First, variable FAMILY showed a significant positive $(+)$ correlation at $1 \%$ significance level with variable BOND. This correlation implies family firm has a positive effect on credit rating. 
Table 3. Pearson's correlation

\begin{tabular}{|c|c|c|c|c|c|c|c|c|}
\hline & FAMILY & SIZE & LEV & ROA & MB & INTCOV & BETA & ALTMANZ \\
\hline \multirow{2}{*}{ BOND } & 0.079 & 0.651 & -0.248 & 0.410 & 0.075 & 0.196 & -0.084 & 0.231 \\
\hline & $(<.0001)$ & $(<.0001)$ & $(<.0001)$ & $(<.0001)$ & $(0.0002)$ & $(<.0001)$ & $(<.0001)$ & $(<.0001)$ \\
\hline \multirow{2}{*}{ FAMILY } & & -0.182 & -0.112 & -0.008 & -0.189 & 0.004 & 0.051 & -0.077 \\
\hline & & $(<.0001)$ & $(<.0001)$ & $(0.6697)$ & $(<.0001)$ & $(0.8382)$ & $(0.0094)$ & $(<.0001)$ \\
\hline \multirow{2}{*}{ SIZE } & & & 0.179 & 0.182 & 0.123 & 0.047 & 0.178 & 0.008 \\
\hline & & & $(<.0001)$ & $(<.0001)$ & $(<.0001)$ & $(0.0168)$ & $(<.0001)$ & $(0.7046)$ \\
\hline \multirow{2}{*}{ LEV } & & & & -0.357 & 0.142 & -0.299 & 0.227 & -0.564 \\
\hline & & & & $(<.0001)$ & $(<.0001)$ & $(<.0001)$ & $(<.0001)$ & $(<.0001)$ \\
\hline \multirow{2}{*}{ ROA } & & & & & 0.029 & 0.251 & -0.098 & 0.268 \\
\hline & & & & & $(0.1456)$ & $(<.0001)$ & $(<.0001)$ & $(<.0001)$ \\
\hline \multirow{2}{*}{ MB } & & & & & & 0.082 & 0.096 & 0.514 \\
\hline & & & & & & $(<.0001)$ & $(<.0001)$ & $(<.0001)$ \\
\hline \multirow{2}{*}{ INTCOV } & & & & & & & -0.078 & 0.406 \\
\hline & & & & & & & $(<.0001)$ & $(<.0001)$ \\
\hline \multirow{2}{*}{ BETA } & & & & & & & & -0.085 \\
\hline & & & & & & & & $(<.0001)$ \\
\hline
\end{tabular}

Variable definitions: refer to Table 2. Values in parentheses are p-values.

\section{Multivariate Regression Analysis}

The results of a regression analysis to verify a hypothesis are presented in $<$ Table $4>$. When credit rating agencies recognize the excellent or poor governance structure of family companies to reflect it in the evaluation of a company's ability to pay back the debt, family companies may get higher or lower credit ratings than non-family companies.

As a result, the regression coefficient of FAMILY in a linear regression model is $0.291(\mathrm{t}=2.65)$. It is shown that FAMILY has a significantly positive $(+)$ effect on the bond credit rating, a dependent variable, at the level of $1 \%$. This result means that higher credit ratings are given to family companies than non-family companies. It shows that credit rating agencies evaluate family companies to have better governance structures than those of non-family companies.

Table 4: Effect of Family Firm on CreditRating

\begin{tabular}{|c|c|c|c|}
\hline \multicolumn{4}{|c|}{$i t+1=\beta 0+\beta 1 i t+\beta 2 i t+\beta 3$ Vit $+\beta 4 i t+\beta 5 i t+\beta 6$ Vit $+\beta 7 i t+\beta 8 i t+\epsilon i t$} \\
\hline \multirow{2}{*}{ Variables } & \multirow{2}{*}{ Expected Sign } & \multicolumn{2}{|c|}{ Dependent Variable: BOND } \\
\hline & & Coefficient & t Value \\
\hline Intercept & $?$ & -17.45 & $-24.99^{* * *}$ \\
\hline FAMILY & $?$ & 0.291 & $2.65^{* * *}$ \\
\hline SIZE & + & 1.674 & $50.74^{* * *}$ \\
\hline LEV & - & -6.481 & $-15.45^{* * *}$ \\
\hline ROA & + & 8.759 & $11.94^{* * *}$ \\
\hline MB & + & 0.322 & $4.3^{* * *}$ \\
\hline INTCOV & + & 0.002 & $2.43^{* *}$ \\
\hline BETA & - & -1.145 & $-10.15^{* * *}$ \\
\hline ALTMANZ & + & -0.0002 & $-2.2^{* *}$ \\
\hline Industry dummy & $\mathrm{N} / \mathrm{A}$ & \multicolumn{2}{|c|}{ Included } \\
\hline Year dummy & $\mathrm{N} / \mathrm{A}$ & \multicolumn{2}{|c|}{ Included } \\
\hline F-Value & & \multicolumn{2}{|c|}{$208.69 * * *$} \\
\hline Adjusted $\mathrm{R}^{2}$ & & \multicolumn{2}{|c|}{0.607} \\
\hline $\mathrm{N}$ & & \multicolumn{2}{|c|}{2,555} \\
\hline
\end{tabular}




\section{Effect of Family Firm on Credit Rating Measured as Commercial Paper (Additional Test1)}

The same analysis was made for commercial paper ratings as the first additional verification for a robustness test. Credit ratings were divided into bond and commercial paper ratings. The long- and the short-term ratings were respectively applied to bonds and commercial papers. In case of commercial papers, 12 points were given to the highest $\mathrm{A} 1$ grade, while 1 point was given to the lowest $\mathrm{D}$ grade. The results of the additional analysis that a hypothesis was re-verified with commercial paper ratings as a dependent variable are shown in $\langle$ Table $5>$. The regression coefficient of FAMILY identifies the robustness of the result of hypothesis testing, showing $0.202(\mathrm{t}=1.74)$, a significantly positive $(+)$ value at the level of $1 \%$.

Table 5. Effect of Family Firm on Credit Rating Measured as Commercial Paper (Additional Test 1)

\begin{tabular}{|c|c|c|c|}
\hline \multirow{2}{*}{ Variables } & \multirow{2}{*}{ Expected Sign } & \multicolumn{2}{|c|}{ Dependent Variable: CP } \\
\hline & & Coefficient & t Value \\
\hline Intercept & ? & -17.699 & $-21.75^{* * *}$ \\
\hline FAMILY & $?$ & 0.202 & $1.74^{*}$ \\
\hline SIZE & + & 1.376 & $36.91^{* * *}$ \\
\hline LEV & - & -3.992 & $-8.49^{* * *}$ \\
\hline ROA & + & 3.841 & $4.14^{* * *}$ \\
\hline MB & + & 0.182 & $2.2^{* *}$ \\
\hline INTCOV & + & 0.002 & $2.18^{* *}$ \\
\hline BETA & - & -1.01 & $-8.57^{* * *}$ \\
\hline ALTMANZ & + & 0 & $2.83^{* * *}$ \\
\hline Industry dummy & $\mathrm{N} / \mathrm{A}$ & \multicolumn{2}{|c|}{ Included } \\
\hline Year dummy & N/A & \multicolumn{2}{|c|}{ Included } \\
\hline F-Value & & \multicolumn{2}{|c|}{$120.86^{* * *}$} \\
\hline Adjusted $\mathrm{R}^{2}$ & & \multicolumn{2}{|c|}{0.609} \\
\hline $\mathrm{N}$ & & \multicolumn{2}{|c|}{1,304} \\
\hline
\end{tabular}

Notes: ***,**, and * represent significance at the 1, 5, and 10 percent levels, respectively.

CP: Commercial Paper(1 12points)

Other variable definitions: refer to Table 2.

\section{Effect of Family Firm and Chaebol on Credit Rating (Additional Test 2)}

There is a group of large-scale companies, called conglomerates, in Korea. They have exercised a great influence on the Korean economy. Even though they have a positive effect on the Korean economy, they also exercise a harmful effect with the formation of monopolies. This study intended to test how family companies which are conglomerates had influenced credit ratings as the second additional verification. When family companies which are conglomerates have a positive effect on credit ratings, the coefficient value of the interaction variable between FAMILY and CHAEBOL in $<$ Table $6>$ will be positive $(+)$. On the other hand, when family companies which are conglomerates are negatively evaluated by credit rating agencies, the above value will be negative (-). As a result of an empirical analysis, the relevant value is shown to be $-0.625(\mathrm{t}=-2.86)$, a significantly negative value at the level of $1 \%$. Namely, this study shows that credit rating agencies recognize family companies which are conglomerates to have negative corporate governance structures. 
Table 6. Effect of Family Firm and Chaebol on CreditRating (Additional Test 2)

\begin{tabular}{|c|c|c|c|}
\hline \multirow{2}{*}{ Variables } & \multirow{2}{*}{ Expected Sign } & \multicolumn{2}{|c|}{ Dependent Variable: CP } \\
\hline & & Coefficient & t Value \\
\hline Intercept & $?$ & -14.698 & $-16.18^{* * *}$ \\
\hline FAMILY & $?$ & 0.537 & $3.95^{*}$ \\
\hline CAHEBOL & & 1.149 & $5.62^{* * *}$ \\
\hline FAMILYxCHAEBOL & & -0.625 & $-2.86^{* * *}$ \\
\hline SIZE & + & 1.528 & $34.88^{* * *}$ \\
\hline LEV & - & -6.455 & $-15.46^{* * *}$ \\
\hline ROA & + & 9.024 & $12.36^{* * *}$ \\
\hline MB & + & 0.279 & $3.73^{* * *}$ \\
\hline INTCOV & + & 0.002 & $2.39^{* *}$ \\
\hline BETA & - & -1.228 & $-10.84^{* * *}$ \\
\hline ALTMANZ & + & 0 & $-2.01^{* *}$ \\
\hline Industry dummy & $\mathrm{N} / \mathrm{A}$ & \multicolumn{2}{|c|}{ Included } \\
\hline Year dummy & $\mathrm{N} / \mathrm{A}$ & \multicolumn{2}{|c|}{ Included } \\
\hline F-Value & & \multicolumn{2}{|c|}{$192.79^{* * *}$} \\
\hline Adjusted $\mathrm{R}^{2}$ & & \multicolumn{2}{|c|}{0.609} \\
\hline $\mathrm{N}$ & & \multicolumn{2}{|c|}{2,555} \\
\hline
\end{tabular}

Notes: ***,**, and * represent significance at the 1,5 , and 10 percent levels, respectively. CHAEBOL: 1 if firms belongs to a conglomerate, O otherwise. Other variable definitions: refer to Table 2.

\section{SUMMARY ANDCONCLUSION}

This study analyzed the effects of Korean family companies on credit ratings. Family companies had been measured in various ways in previous studies. In this study, the company was classified as a family company because it was judged the company owner's family member exercised a significant impact on the corporate management when he or she participated in the corporate management and held shareholdings representing at least $5 \%$ of shares and voting rights in the company. The result of analyzing 2,555 companies which had got credit ratings from credit rating agencies between 2000 and 2010 is summarized as follows: Above all, it is shown that credit rating agencies had given higher credit ratings to family companies than non-family companies. It is assumed that Korean credit rating agencies judged that family companies had good governance structures to have a positive effect on corporate values. These results are shown to be consistent with those of the additional verification on the measurement of credit ratings with commercial paper ratings. However, the result is that credit rating agencies perceived family companies which are conglomerates negatively. It is shown that Korean conglomerates were evaluated to have poor governance structures when the owners actually participated in the corporate management.

This study is very meaningful as the first study which investigated the effects of Korean family companies on credit ratings. In addition, it is shown that credit rating agencies recognized family-run companies to play a positive role in the governance structure, and gave high credit ratings to them. Accordingly, this study makes a contribution in that it investigated the response of the capital market to Korean family companies.

\section{AUTHOR BIOGRAPHIES}

Soo-Joon Chae, Ph.D., Professor of Accounting, School of Business, Kangwon National University, 192- 1 Hyojadong, Chuncheon, Gangwon-do, Korea. E-mail: sjchae@kangwon.ac.kr (Main Author)

Kwangwuk Oh, Ph.D., Professor of Division of Business Administration at Korea University, 2511 Sejong-ro, Sejong City, S. Korea. E-mail: avnini92@korea.ac.kr (Corresponding Author) 


\section{REFERENCES}

Ashbaugh-Skaife, H., D. W. Collins, and R. LaFond. 2006. The effect of corporate governance on firm's credit ratings. Journal of Accounting and Economics 42:203-243.

Bhojraj, S., and P. Sengupta. 2003. Effect of Corporate Governance on Bond Ratings and Yields: The Role of Institutional Investors and Outside Directors. Journal of Business 76:455-475.

Bushman, R., and A. Smith. 2001. Financial accounting information and corporate governance. Journal of Accounting and Economics 32: 237-333.

Dichev, I., and Skinner, D. 2002. Large-sample evidence on the debt covenant hypothesis. Journal of Accounting Research 40: 1091-1124.

Faccio, M., L. Lang., and L. Young 2001, "Dividends and Expropriation," The American Economic Review, 91, 1, 54-78.

Fama, E., and M. Jensen 1983, "Separation of Ownership and Control," Journal of Law and Economics 26, $301-326$.

Fitch Ratings. 2004. Credit Policy Special Report: Evaluating Corporate Governance: The Bondholder's Perspective. New York.

Francis, J. R, I. K. Khurana., and R. Pereira. 2005. Disclosure Incentives and Effects on Cost of Capital around the World. The Accounting Review 80: 1125-1162.

Gode, D., and P. Mohanram. 2003. Inferring the cost of capital using the Ohlson-Juettner model. Review of Accounting Studies 8: 399-431.

Handler, W. C. 1989, "Methodological Issues and Consideration in Studying Family Businesses," Family Business Review, 2, 3, 257-276.

Jensen, M. C., and W.H. Meckling. 1976. Theory of the Firm: Managerial Behavior, Agency Costs, and Ownership Structure. Journal of Financial Economics 3: 305-360.

Klein, A. 2002. Audit committee, board of director characteristics, and earnings management. Journal of Accounting \& Economics 33: 375-400.

LaFond, R., and S. Roychowdhury 2008, "Managerial Ownership and Accounting Conservatism," Journal of Accounting Research, 46, 1, 101-135.

Morck, R., A. Shleifer., and R. Vishny 1988, "Management and Ownership and Market Valuation: An Empirical Analysis," Journal of Financial Economics, 20, 293-315.

Sengupta, P. 1998. Corporate disclosure quality and the cost of debt. The Accounting Review 73:459-474.

Smith, C., and Warner, J. 1979. On Financail Reporting: An Analysis of Bond Covenants. Journal of Financial Economics 7: 117161.

Standard \& Poor's. 2001. Standard \& Poor's Corporate Rating Criteria. Available at http://www.corporatecriteria.standardandpoors.com

Standard \& Poor's. 2002. Standard \& Poor's Corporate Governance Scores: Criteria, Methodology and Definitions. McGraw-Hill Companies, Inc., New York.

Verrecchia, R. 1983. Discretionary disclosure. Journal of Accounting and Economics 5: 179-194.

Wang, D. 2006, "Founding Family Ownership and Earnings Quality," Journal of Accounting Research, 44, 3, 619-656.

Westhead, P., and M. Cowling 1998, "Family Firm Research: The Need for a Methodological Rethink," Entrepreneurship Theory and Practice, 23, 31-56. 